\title{
Seasonal changes of plant hydraulics, water relations and growth of Aesculus hippocastanum seedlings infested by the leafminer Cameraria ohridella
}

\author{
Fabio RAIMONDO, Patrizia TRIFILÒ, Sebastiano SALLEO, Andrea NARDINI* \\ Dipartimento di Biologia, Università degli Studi di Trieste, via L. Giorgieri 10, 34127 Trieste, Italy
}

(Received 19 January 2004; accepted 8 April 2004)

\begin{abstract}
The leaf miner Cameraria ohridella causes premature defoliation in Aesculus hippocastanum. The impact of the parasite on seasonal changes of water relations, hydraulics and growth of three-year-old A. hippocastanum seedlings was investigated. Leaf expansion was complete before the adults of the moth developed, so that growth of infested seedlings was similar to that of controls. Leaf conductance to water vapour of infested seedlings was reduced with respect to controls, both in mined and in still green portions of attacked leaves. In July and August, the hydraulic resistance of infested seedlings was higher than that of controls, due to anticipated increase of hydraulic resistance at the leaf, petiole and current-year stem level. This was interpreted as evidence of anticipated leaf senescence in infested plants, leading to early leaf abscission. Nevertheless, our data suggest that, under our experimental conditions, C. ohridella is not a major mortality factor for A. hippocastanum seedlings.
\end{abstract}

Cameraria ohridella / Aesculus hippocastanum / seedling / hydraulic resistance / leaf

\begin{abstract}
Résumé - Variations saisonnières des propriétés hydrauliques, des relations hydriques et de la croissance de jeunes plants d'Aesculus hippocastanum infestés par la mineuse foliaire Cameraria ohridella. La mineuse foliaire Cameraria ohridella provoque des défoliations prématurées chez le Marronnier (Aesculus hippocastanum). L'impact du parasite sur les variations saisonnières des relations hydriques, des paramètres hydrauliques et de la croissance de plants d'A. hippocastanum âgés de 3 ans a été analysé. L'expansion foliaire étant terminée avant que les adultes de l'insecte soient développés, la croissance des plants infestés fut similaire à celle des plants témoins. La conductance foliaire à la vapeur d'eau des plants infestés fut réduite par rapport aux témoins, que ce soit dans les parties encore vertes des feuilles ou dans les parties attaquées. En juillet et août, la résistance hydraulique des plants infestés fut plus élevée que celle des témoins, en raison d'une augmentation anticipée de la résistance hydraulique des feuilles, des pétioles et des tiges de l'année. Ceci fut interprété comme une preuve d'une anticipation de la sénescence foliaire pour les plants infestés, conduisant à une abscission prématurée des feuilles. Néanmoins, nos données suggèrent que, dans nos conditions expérimentales, $C$. ohridella n'est pas un facteur majeur de mortalité pour les jeunes plant d'A. hippocastanum.
\end{abstract}

Cameraria ohridella / Aesculus hippocastanum / jeune plant / résistance hydraulique / feuille

\section{INTRODUCTION}

The leaf miner Cameraria ohridella Deschka et Dimic (Lepidoptera, Gracillariidae) is a moth whose larvae feed on the foliage of Aesculus hippocastanum L. (horse chestnut). In particular, larvae extensively tunnel the palisade parenchyma of the leaves producing typical mines where upper and lower epidermis, spongy parenchyma and veins are left intact [13]. In recent years, the moth has become a serious pest $[5,12]$ because it causes severe and premature defoliation of horse chestnut plants which are very common ornamentals of streets, parks and gardens in European cities. Previous studies [13, 16, 17] have shown that $A$. hippocastanum plants attacked by the parasite suffer a major damage in terms of reproductive potential (they produce smaller seeds with limited viability). On the contrary, whole-plant photosynthetic productivity and hydraulics of adult plants did not seem to be heavily affected $[13,16]$, as recently confirmed on the basis of a mathematical model taking into account seasonal changes of photosynthetic rate and damage to foliage [9]. However, little is known of the potential impact of $C$. ohridella on the hydraulics and productivity of horse chestnut seedlings. Although natural propagation of $A$. hippocastanum is of no interest for urban arboriculture, it has to be taken into proper account that the species is an important component of natural forests in the Balkans, where eventual negative effects on plant reproduction and seedlings' productivity and survival might have important consequences at the ecosystem level $[4,6,19]$.

Several studies show that seedlings are more vulnerable to stress factors with respect to adult plants $[1,3,7]$. Therefore, the impact of $C$. ohridella on seedlings of $A$. hippocastanum can be hypothesized to be larger than that on adult individuals of the same species. To test this hypothesis, seasonal changes of plant hydraulics, water relations and growth rate were measured

\footnotetext{
* Corresponding author: nardini@univ.trieste.it
} 
of horse chestnut seedlings either infested by the leaf miner or protected from the parasite attacks. The final aim of the present study was to evaluate the risk of mortality in A. hippocastanum seedlings attacked by $C$. ohridella.

\section{MATERIALS AND METHODS}

All experiments were performed between the year 2002 and 2003 on 300 three-year-old seedlings of A. hippocastanum. Before planting, potted seedlings had a height of $0.60 \pm 0.06 \mathrm{~m}$ and a trunk diameter of $10.1 \pm 2.5 \mathrm{~mm}$. Seedlings were grown in a custom-made greenhouse in the Botanical Garden of the University of Trieste at $120 \mathrm{~m}$ above the sea level. The greenhouse was built with steel chassis and wood supports and it was completely covered with a net (knitted fabric $0.5 \mathrm{~mm}$ ) in order to prevent the free entrance of $C$. ohridella and other parasites within the greenhouse. The same net was used to divide the greenhouse into two different sections of similar dimensions. Soil inside the greenhouse was ploughed and blended with peat in February 2002. Seedlings were randomly divided into two groups and planted in early March 2002 with $0.3 \mathrm{~m}$ spacing between plants. The greenhouse was equipped with an irrigation system and seedlings were irrigated twice per week starting from early April till September.

In one section of the greenhouse, the ground was covered with leaf litter collected under adult horse chestnut trees that had been heavily infested by the moth the previous year. This procedure had the aim to favour leaf miner attack in one group of seedlings by adults emerging from pupae overwintering in the dead foliage. This group of seedlings was named "infested" (I) and compared to the other control (C) group whose infestation by $C$. ohridella was prevented by the presence of the net. Our experimental set-up allowed to grow C- and I-plants under the same environmental conditions, the only difference between groups being the presence or absence of the parasite.

\subsection{Measuring seedling growth and leaf damage}

In order to check whether $C$. ohridella infestation causes an alteration of the seedlings' growth potential, the following variables were recorded every week on both C-and I-plants (12 seedlings per group): (a) total stem length; (b) current-year stem length; (c) trunk diameter $20 \mathrm{~mm}$ above the ground; (d) total leaf surface area; (e) percentage of leaf surface area covered by mines. Stem length was measured using a rule and trunk diameter was measured using a digital caliper (Mitutoyo mod. 500). In order to measure total leaf surface area $\left(\mathrm{A}_{\mathrm{L}}\right)$ without removing the foliage from seedlings, 25 leaves were collected and the surface area of each leaflet was measured using a leaf area meter (LI3000A, LiCor Inc.). The same leaflets were measured for their maximum length and maximum width using a rule. These dimensions were multiplied by each other and the result was plotted versus the corresponding leaflet surface area, thus obtaining a conversion factor between the two parameters (Actual leaf surface area $=0.563 \times$ leaf length $\times$ leaf width, $r=0.997, P<0.0001)$. Because the relationship between the two turned out to be closely linear, hereafter only leaf length and width of leaflets were measured and leaf surface area was obtained by conversion. Starting from early May, when the first adults of $C$. ohridella were observed in the I-section of the greenhouse, 20 leaves per week and per group were randomly collected from seedlings of both groups and the mined leaf surface area was measured using a leaf area meter (see above) and paper replicas of mines' area. All morphological measurements were undertaken between April and September 2002 and they were repeated in April, May and June 2003.

\subsection{Measuring plant water relation parameters}

In order to check the eventual alterations of seedlings' water status caused by $C$. ohridella attacks, the midday leaf conductance to water vapour $\left(\mathrm{g}_{\mathrm{L}}\right)$ and water potential $\left(\Psi_{\mathrm{L}}\right)$ were measured on both groups of plants at two weeks intervals between April and September 2002. Measurements were always performed one to two days after the last irrigation. Measurements were performed at $1 \mathrm{~h}$ intervals between $11.00 \mathrm{~h}$ and $14.00 \mathrm{~h}$. At least 8 leaves per group of plants and per daytime were measured for $g_{L}$ using a steady-state porometer (LI1600, LiCor Inc.) equipped with a narrow chamber $\left(60 \mathrm{~mm}^{2}\right.$ surface area). The narrow chamber allowed to measure leaf gas exchange of control leaves as well as of mined and green areas even in heavily infested leaves. Leaf water potential was measured of at least two leaves per group and per daytime using a portable pressure chamber (3005 Plant Water Status Console, Soilmoisture Equipment Corp., Goleta, CA, USA) with wet paper inside the chamber to minimize water loss during measurements.

In order to check eventual changes of solute accumulation and cell walls properties as induced by the leaf miner infestation, leaf water potential isotherms were measured of 4 leaves per group at two weeks intervals. Briefly, leaves were collected the evening preceding the experiments and their petiole was put in contact with distilled water. Leaves were rehydrated in the dark, overnight, to full turgor. Then, pressure-volume (PV) curves were obtained using the procedure described by Salleo [14] and leaf osmotic potential at full turgor $\left(\pi_{0}\right)$ and leaf water potential at the turgor loss point $\left(\Psi_{\mathrm{tlp}}\right)$ were calculated.

\subsection{Measuring plant hydraulics}

Eventual changes in the plant hydraulic properties as induced by C. ohridella attacks were estimated in terms of root $\left(\mathrm{R}_{\text {root }}\right)$ and shoot $\left(\mathrm{R}_{\text {shoot }}\right)$ hydraulic resistance that were measured using a high pressure flow meter (HPFM) [18], at two weeks intervals between April and September 2002. Briefly, the HPFM consists of an apparatus that allows the perfusion of distilled water (filtered at $0.1 \mu \mathrm{m}$ ) into the base of a root system or a shoot while rapidly changing the applied pressure (P) and simultaneously measuring the corresponding flow. The instrument has been successfully used to measure the hydraulics of whole root systems in situ $[8,10]$ as well as the partitioning of hydraulic resistances within the shoot $[11,20]$. Shoots were excised from the roots (about $10 \mathrm{~cm}$ above the soil) under water by constructing a watertight container around the base of each plant. The HPFM was connected to the root system and three to six transient flow measurements were immediately performed. During each measurement, $\mathrm{P}$ was increased at a rate of $5-8 \mathrm{kPa} \mathrm{s}^{-1}$ while measuring the flow every $3 \mathrm{~s}$. The entire sequence of flow measurements took about $5 \mathrm{~min}$. The flow was then plotted versus the applied pressure and $\mathrm{R}$ was calculated from the slope of the $\mathrm{P}$ to $\mathrm{F}$ linear regression. During $\mathrm{R}_{\text {root }}$ measurements, the shoots remained with the cut surface immersed in water while enclosed in plastic bags to prevent evaporation. The base of the stem was connected to the HPFM and the stem was perfused at a pressure of $0.3 \mathrm{MPa}$ for $30 \mathrm{~min}$. Then, the pressure was decreased to $0.03 \mathrm{MPa}$ and maintained constant for $10 \mathrm{~min}$. Three to five transient measurements were performed and $\mathrm{R}$ was calculated as described above. Leaf blades were then removed and $\mathrm{R}$ was measured again so that leaf hydraulic resistance was calculated from:

$$
\mathrm{R}_{\text {leaf }}=\mathrm{R}_{\text {shoot }}-\mathrm{R}_{\text {residual }}
$$

where $\mathrm{R}_{\text {residual }}$ is the hydraulic resistance measured after removal of leaf blades. The procedure was repeated with petioles and current-year (cy) stems, thus obtaining $R_{\text {petiole }}$ and $R_{\text {cy-stem. }}$ All measurements were corrected for temperature. At the end of each experiment, the leaf surface area $\left(A_{L}\right)$ of the seedlings was measured using the leaf area meter (see above) and $\mathrm{R}$ values were multiplied by $\mathrm{A}_{\mathrm{L}}$ in order to normalize them for seedlings' dimensions. Total plant hydraulic hydraulic resistance $\left(\mathrm{R}_{\text {plant }}\right)$ was finally calculated from:

$$
\mathrm{R}_{\text {plant }}=\mathrm{R}_{\text {root }}+\mathrm{R}_{\text {shoot }} \text {. }
$$




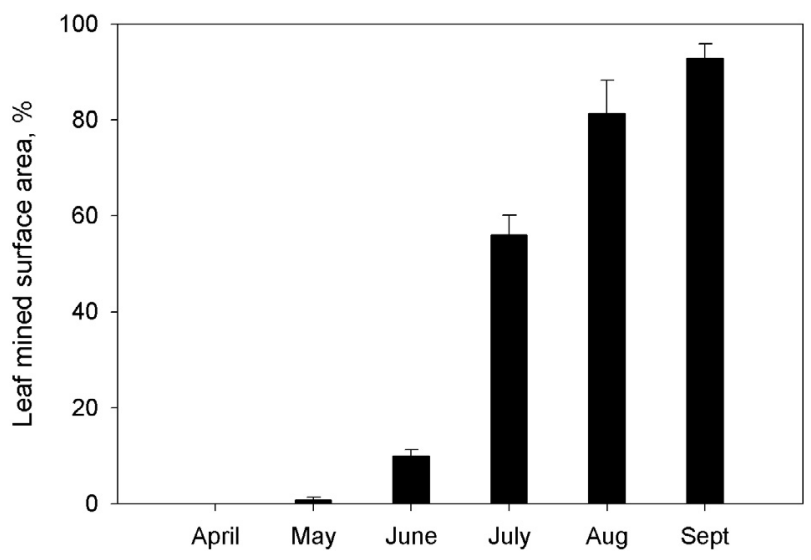

Figure 1. Seasonal changes of percentage of leaf mined surface area as measured in infested seedlings during year 2002. Means are reported $\pm \mathrm{SD}(n=20)$

\section{RESULTS}

In the course of year 2002, control seedlings did not show symptoms of $C$. ohridella attack thus confirming that the net cover was effective in preventing casual infestation by the moth. On the contrary, several adult moths emerging from the leaf litter were observed in the "infested" section starting from the end of April. Mines became apparent starting from May (Fig. 1) but only in June did the leaf mined area increase to above $10 \%$. Later on, the percentage of damage increased dramatically up to about 55, 80 and 90\% in July, August and September, respectively (Fig. 1).

C- and I-plants did not show any significant difference in terms of total leaf surface area developed during 2002 and 2003 (Fig. 2). Complete leaf expansion occurred within the end of April and early May i.e. before leaf mining produced significant damage to the foliage. At the end of June 2002, total leaf surface area of seedlings was about $0.2 \mathrm{~m}^{2}$. Also in 2003, measurements revealed no significant difference between $C$ - and I-seedlings and total leaf surface area in June was about $0.5 \mathrm{~m}^{2}$, with a significant increment with respect to year 2002. Moreover, no significant difference between C- and I-plants was found in terms of current-year stem length $\left(\mathrm{L}_{\mathrm{cy}}\right)$ and trunk diameter $\left(\varnothing_{\mathrm{T}}\right)$, thus suggesting that infestation by the moth did not induce any significant change in the growth potential and pattern of $A$. hippocastanum seedlings (Tab. I).

\subsection{Leaf gas exchange and water relations parameters}

In late April 2002, when leaf expansion was almost complete and leaves had not suffered any damage yet, maximum $\mathrm{g}_{\mathrm{L}}$ recorded was about $160 \mathrm{mmol} \mathrm{m}^{-2} \mathrm{~s}^{-1}$ with no significant difference between seedlings growing in the $\mathrm{C}$ - or I-section of the greenhouse (Fig. 3). During the course of the season, $\mathrm{g}_{\mathrm{L}}$ remained more or less constant in C-plants, while it showed to decrease in I-ones. This $\mathrm{g}_{\mathrm{L}}$ reduction was only partial in green parts of infested leaves with respect to controls but it was very marked at the mine level. As an example, in July 2002, g $\mathrm{g}_{\mathrm{L}}$ was about 160, 130 and $60 \mathrm{mmol} \mathrm{m}^{-2} \mathrm{~s}^{-1}$ in control leaves and in green and mined portions of infested leaves, respectively

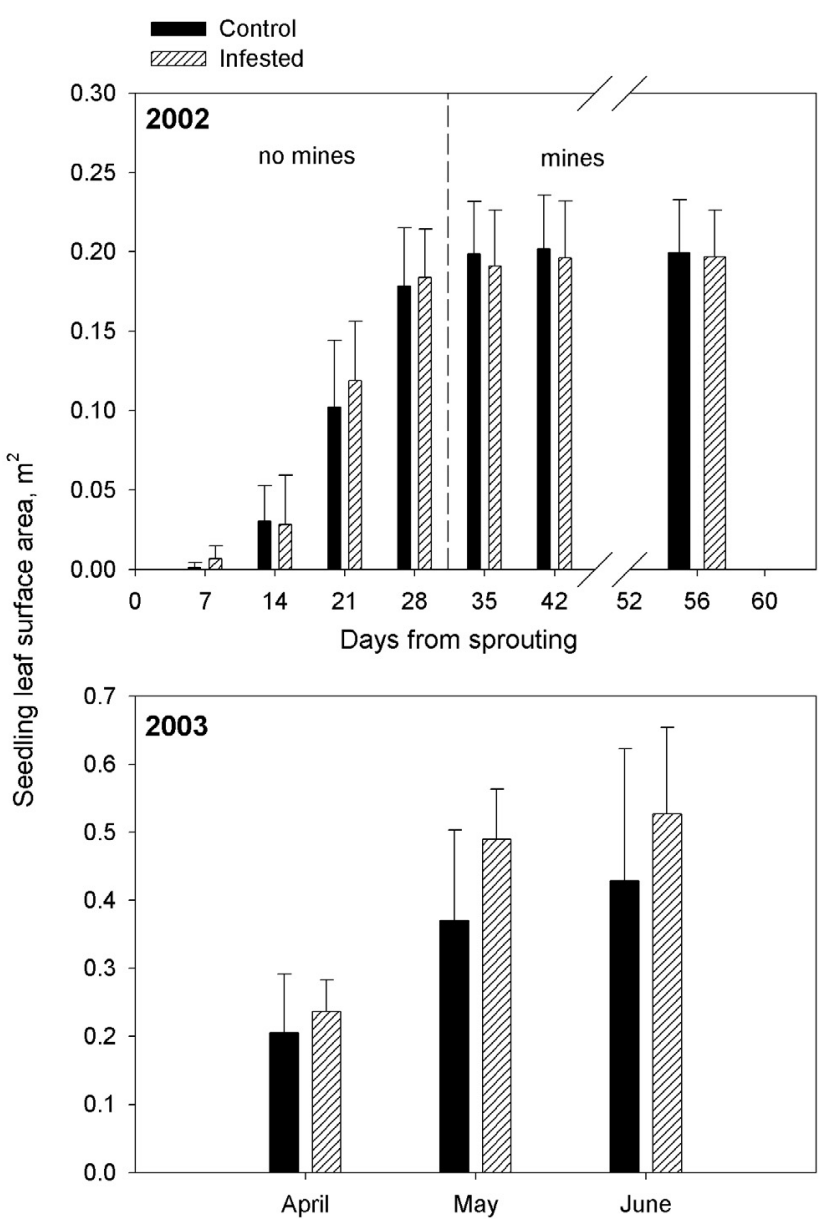

Figure 2. Seasonal changes of seedling leaf surface area as measured in control (black columns) and infested (dashed columns) seedlings during the first (2002) and second (2003) year of attacks by C. ohridella. Means are reported $\pm \operatorname{SD}(n=20)$.

Table I. Total leaf surface area $\left(\mathrm{A}_{\mathrm{L}}\right)$, length of current-year stem $\left(\mathrm{L}_{\mathrm{cy}}\right)$ and trunk diameter $\left(\varnothing_{\mathrm{T}}\right)$ of control and infested seedlings as measured after complete leaf expansion $\left(\mathrm{A}_{\mathrm{L}}\right)$ or after complete foliage loss $\left(\mathrm{L}_{\mathrm{cy}}\right.$ and $\left.\varnothing_{\mathrm{T}}\right)$. Means are reported $\pm \mathrm{SD}(n=12)$. n.s. $=$ not significant.

\begin{tabular}{lccl}
\hline & Control & Infested & \\
\hline $\mathrm{A}_{\mathrm{L}}, \mathrm{m}^{2}$ & $0.43 \pm 0.19$ & $0.53 \pm 0.13$ & n.s. \\
$\mathrm{L}_{\mathrm{CY}}, \mathrm{m}$ & $0.27 \pm 0.12$ & $0.25 \pm 0.10$ & n.s. \\
$\varnothing_{\mathrm{T}}, \mathrm{mm}$ & $12.2 \pm 2.10$ & $13.9 \pm 1.87$ & n.s. \\
\hline
\end{tabular}

(Fig. 3). In September, $g_{\mathrm{L}}$ decreased to about $60 \mathrm{mmol} \mathrm{m}^{-2} \mathrm{~s}^{-1}$ both in control leaves and in green portions of infested ones.

Although statistically significant differences between Cand I-seedlings were apparent in terms of leaf gas exchange rates, this did not translate into significant differences in terms of $\Psi_{L}$ (Fig. 4). Leaf water potential showed quite high values 


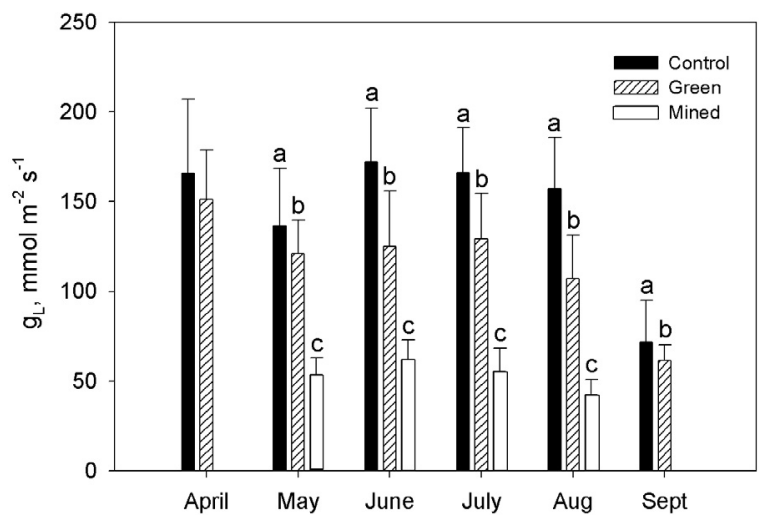

Figure 3. Seasonal changes of leaf conductance to water vapour $\left(\mathrm{g}_{\mathrm{L}}\right)$ as measured in control leaves (black columns) and in green (dashed columns) and mined (white columns) areas of infested leaves. Means are reported $\pm \mathrm{SD}(n=8)$. Different letters indicate significant differences $(P<0.05)$ for Tukey pairwaise comparisons.

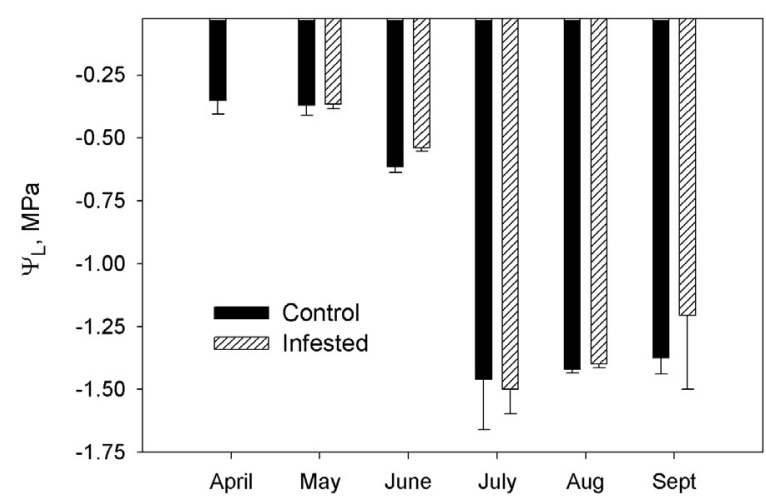

Figure 4. Seasonal changes of leaf water potential $\left(\Psi_{L}\right)$ as measured for leaves of control (black columns) and infested (dashed columns) seedlings. Mean are reported $\pm \mathrm{SD}(n=8)$.

until June ( $\left.\Psi_{\mathrm{L}} \geq-0.6 \mathrm{MPa}\right)$ and decreased markedly to about $-1.50 \mathrm{MPa}$ only in July and similar values were maintained until September. This $\Psi_{L}$ decrease was the likely result of increased air temperatures which, in turn, induced higher transpiration rates and water loss. In accordance with the lack of statistically significant differences between C- and I-seedlings in terms of the $\Psi_{\mathrm{L}}$ seasonal time course, the infestation by C. ohridella did not induce modifications of solute accumulation or of cell wall properties in attacked plants, as indicated by the lack of significant difference between infested plants and controls in terms of $\pi_{0}$ and $\Psi_{\text {tlp }}$ (Fig. 5). A slightly significant difference between $\mathrm{C}$ - and I-plants in this respect was recorded only in August (Fig. 5).

\subsection{Seedlings' hydraulics}

Whole-plant hydraulic resistance turned out to be not statistically different between controls and infested seedlings up to June (Fig. 6). On the contrary, in July and August plant hydraulic resistance $\left(R_{\text {plant }}\right)$ was significantly higher in infested seedlings. This increase was not due to changes in the hydraulic properties
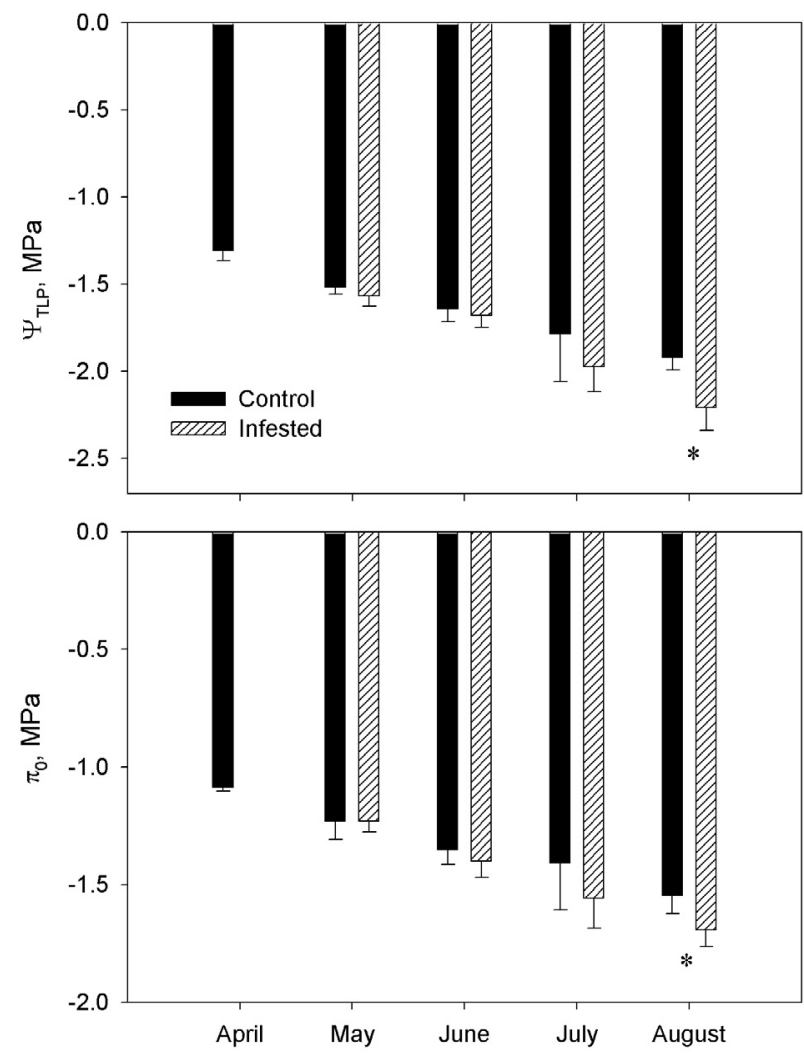

Figure 5. Seasonal changes of leaf water potential at the turgor loss point $\left(\Psi_{\mathrm{tlp}}\right)$ and leaf osmotic potential at full turgor $\left(\pi_{0}\right)$ as estimated from pressure-volume curves for leaves of control (black columns) and infested (dashed columns) seedlings. Means are reported \pm SD $(n=4)$. Statistically significant differences are indicated $(* P<0.05)$.

of the roots, as indicated by the relative constancy of root hydraulic resistance $\left(\mathrm{R}_{\text {root }}\right)$. A detailed analysis of seasonal changes of the hydraulic resistance of different shoot compartments revealed that the reduction in the hydraulic efficiency of infested seedlings was mainly due to a loss of function of current-year stems, although with some contribution of leaves and petioles in this respect (Fig. 6). In particular, the hydraulic resistance of cy-stem $\left(\mathrm{R}_{\mathrm{cy} \text {-stem }}\right)$ was, in July, as high as $1.8 \times$ $10^{3} \mathrm{MPa} \mathrm{s} \mathrm{m} \mathrm{kg}^{-1}$ as compared to about $0.8 \times 10^{3} \mathrm{MPa} \mathrm{s} \mathrm{m} \mathrm{kg}^{-1}$ recorded in controls. It is of interest to note that, in August, the $\mathrm{R}_{\text {cy-stem }}$ of controls increased to values similar to those recorded in infested plants in July. Similar changes were observed for leaf $\left(\mathrm{R}_{\text {leaf }}\right)$ and petiole $\left(\mathrm{R}_{\text {petiole }}\right)$ hydraulic resistances.

\section{DISCUSSION}

During 2002, the first adults of the moth were observed in the greenhouse starting from late April. Until June, however, the percentage of mined leaf surface area remained relatively low (less than 20\%) and only starting from July it increased to high levels (over 50\%, Fig. 1). This attack time course is in accordance with that observed for adult horse chestnut individuals over previous years [9] and has important consequences for plant fitness. In fact, most temperate woody plants complete their leaf expansion and growth by late spring, already, so that 

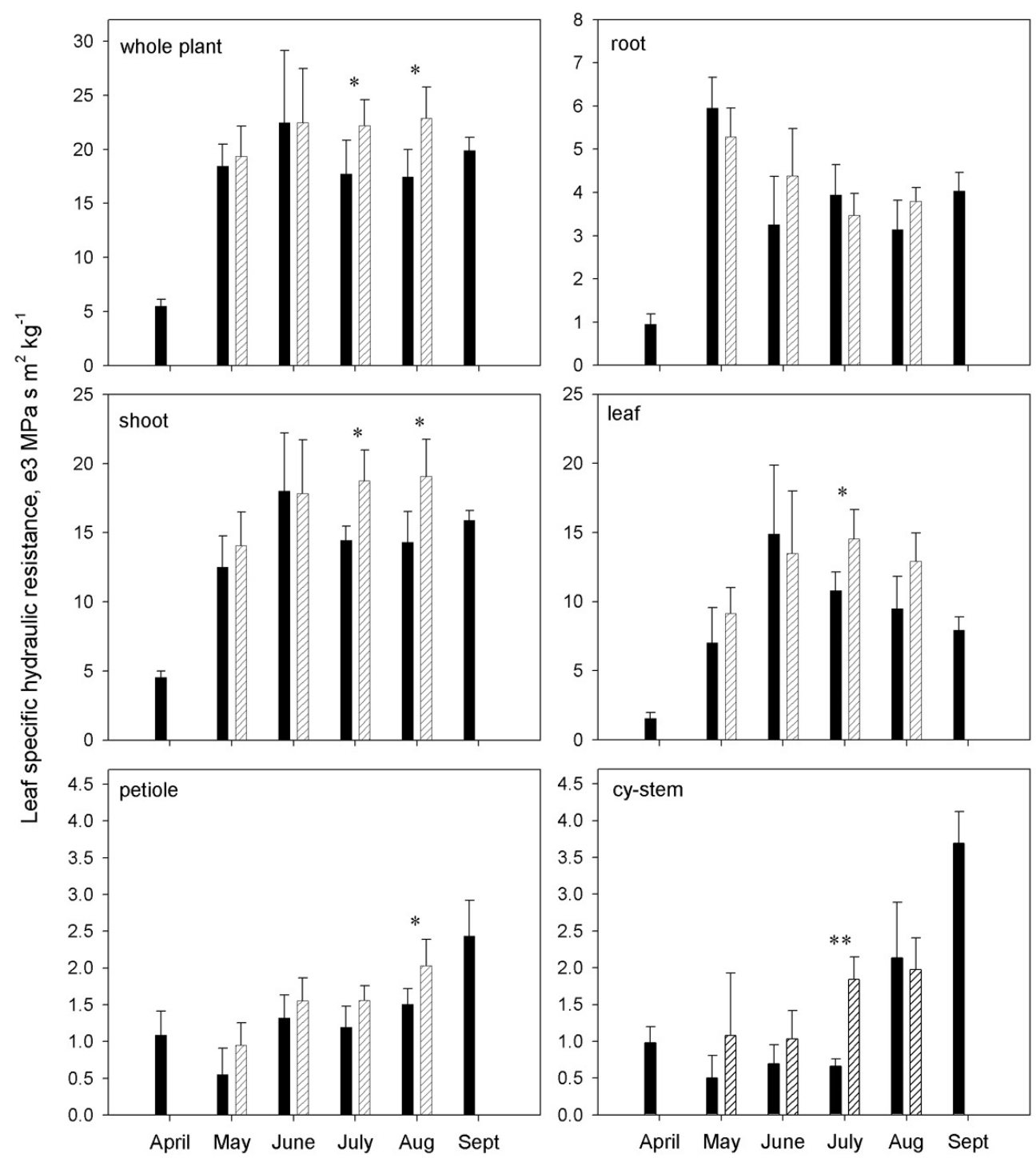

Figure 6. Seasonal changes of leaf specific hydraulic resistance at the whole plant level and for different plant organs, as measured in control (black columns) and infested (dashed columns) seedlings. Means are reported $\pm \operatorname{SD}(n=5)$. Statistically significant differences are indicated $(* P<0.05 ; * * P<0.01)$.

any reduction of photosynthetically active leaf surface area after this time can be expected to have limited impact on annual growth. In particular, our seedlings completed their leaf expansion about 30 days after sprouting and in any case before the first mines became apparent on leaf surface (see Fig. 2). Data relative to seedlings' growth did not reveal any statistically significant difference between control and infested plants in terms of total leaf surface area, stem length or trunk diameter (Fig. 2 and Tab. I). We do not know what the impact could be of severe defoliations repeated over several years on seedlings' growth. However, we note that even after two years of severe moth attack, infested seedlings did not show any growth reduction with respect to controls (Fig. 2). Moreover, all seedlings survived after two years of infestation, so that $C$. ohridella cannot be regarded as a major mortality factor for horse chestnut seedlings, at least under our experimental conditions. It has to be noted, however, that three-year old seedlings were used in the present study, so that no information can be inferred from our data about the risk of mortality associated with the infestation of seedlings during the very early growth stages. In fact, mortality associated with insect herbivory is known to be strongly influenced by seedlings' age [6].

Leaf gas exchange showed to be affected by the leaf miner attack (Fig. 3). Leaf conductance to water vapour was strongly reduced at the mine level with respect to control leaves, and even green portions of infested leaves showed decreased $g_{L}$ values. This effect was not observed in the case of adult plants [13] where $\mathrm{g}_{\mathrm{L}}$ of green portions of infested leaves was unchanged with respect to controls. We do not know the physiological basis for the presence or the absence of borderline effects of mines on the photosynthetic apparatus of still green parts of the leaf blade. We note, however, that due to this effect, the impact 
of the leaf miner on whole plant photosynthetic productivity might be larger in seedlings than in adult trees. The implications of this finding for long-term seedlings' competitivity and survival remain unknown and deserve further studies. In accordance with observations made on adult individuals [13], leaf water status was not affected by the leaf miner attack (Fig. 4), so that no significant osmotic adjustment could be observed in leaves from infested seedlings with respect to controls (Fig. 5). Only in August both $\Psi_{\text {tlp }}$ and $\pi_{0}$ were significantly lower in I-plants with respect to controls (Fig. 5) but the difference was rather small (between 10 and 15\%) and of probably limited physiological significance.

The most interesting effect of the leaf miner on seedlings' physiology was observed at the level of plant hydraulics (Fig. 6). In fact, infested plants showed increased plant hydraulic resistance starting from July. This was associated with increased hydraulic resistance at the leaf, petiole and especially cy-stem level, while root hydraulics was apparently not affected by the parasite. In a previous study by some of us [15], late summer increase of petiole and stem hydraulic resistance was showed to represent a precocious signal leading to leaf senescence and shedding. Similar observations have been reported for leaf hydraulics by Brodribb \& Holbrook [2]. In our opinion, the observed increase of $\mathrm{R}_{\text {leaf }}, \mathrm{R}_{\text {petiole }}$ and $\mathrm{R}_{\text {cy-stem }}$ in horse chestnut seedlings has to be interpreted as evidence of anticipated leaf senescence in infested seedlings with respect to controls, leading to precocious leaf shedding and plant defoliation. In fact, similar increases in $\mathrm{R}$ were observed also in control seedlings where, however, a similar increase in $\mathrm{R}$ was delayed by about one month. As an example, $R_{\text {cy-stem }}$ of

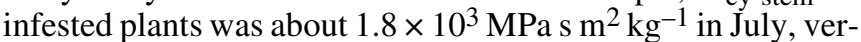
sus only $0.7 \times 10^{3} \mathrm{MPa} \mathrm{s} \mathrm{m} \mathrm{kg}^{-1}$ recorded in controls. In August, however, also $\mathrm{R}_{\text {cy-stem }}$ of controls sharply increased, reaching values similar to those recorded in infested seedlings (about $2.0 \times 10^{3} \mathrm{MPa} \mathrm{s} \mathrm{m} \mathrm{kg}^{-1}$ ). In this view, the premature defoliation of horse chestnut plants attacked by $C$. ohridella should be not regarded as a mere consequence of leaf mining and desiccation, but as a physiological process regulated by the plant in order to eliminate foliage whose photosynthetical activity has been strongly reduced.

In conclusion, our data suggest that repeated attacks of the leaf miner $C$. ohridella do not lead to growth reduction of $A$. hippocastanum seedlings, although leaf gas exchange and plant hydraulics were partly affected by the parasite. In particular, the leaf miner attacks induced anticipated leaf senescence via increased hydraulic impairment at the leaf, petiole and especially cy-stem level. The possible impact of longer term attacks on seedlings' growth, competitivity and survival, as well as the physiological response of seedlings younger than three years of age remains unknown and awaits further investigations possibly addressed at evaluating growth and mortality of horse chestnut seedlings in natural stands.

Acknowledgments: The present study was funded by EU in the framework of the project entitled "Sustainable control of the horse chestnut leafminer, Cameraria ohridella (Lepidoptera, Gracillariidae), a new invasive pest of Aesculus hippocastanum in Europe" (CONTROCAM, Contract No. QLK5-2000-01684).

\section{REFERENCES}

[1] Bragg W.K., Knapp A.K., Briggs J.M., Comparative water relations of seedling and adult Quercus species during gallery forest expansion in tallgrass prairie, For. Ecol. Manage. 56 (1993) 29-41.

[2] Brodribb T.J., Holbrook N.M., Changes in leaf hydraulic conductance during leaf shedding in seasonally dry tropical forest, New Phytol. 158 (2003) 295-303.

[3] Cavender-Bares J., Bazzaz F., Changes in drought response strategies with ontogeny in Quercus rubra: implications for scaling from seedlings to mature trees, Oecologia 124 (2000) 8-18.

[4] Figueroa J.A., Castro S.A., Effect of herbivores and pathogens on the survival and growth of seedlings in a fragment of the Chiloe rainforest, Chile, Rev. Chil. Hist. Nat. 73 (2000) 163-173.

[5] Gilbert M., Svatos A., Lehmann M., Bacher S., Spatial patterns and infestation processes in the horse chestnut leafminer Cameraria ohridella: a tale of two cities, Entomol. Exp. Appl. 107 (2003) 25-37.

[6] Jackson R.V., Bach C.E., Effects of herbivory on growth and survival of seedlings of a rainforest tree, Alphitonia whitei (Rhamnaceae), Aust. J. Ecol. 24 (1999) 278-286.

[7] McNamara S., Pellett H., Cold hardiness of Phellodendron sachalinense Friedr. Schmidt seedlings increases with age, HortScience 35 (2000) 304-305.

[8] Nardini A., Lo Gullo M.A., Salleo S., Competitive strategies for water availability in two Mediterranean Quercus species, Plant Cell Environ. 22 (1999) 109-116.

[9] Nardini A., Raimondo F., Scimone M., Salleo S., Impact of the leaf miner Cameraria ohridella on whole-plant photosynthetic productivity of Aesculus hippocastanum: insights from a model, Trees 18 (2004) 714-721.

[10] Nardini A., Salleo S., Lo Gullo M.A., Pitt F., Different responses to drought and freeze stress of Quercus ilex L. growing along a latitudinal gradient, Plant Ecol. 148 (2000) 141-149.

[11] Nardini A., Tyree M.T., Root and shoot hydraulic conductance of seven Quercus species, Ann. For. Sci. 56 (1999) 371-377.

[12] Pavan F., Barro P., Bernardinelli I., Gambon N., Zandigiacomo P., Cultural control of Cameraria ohridella on horsechestnut in urban areas by removing fallen leaves in autumn, J. Arboric. 29 (2003) 253-258.

[13] Raimondo F., Ghirardelli L.A., Nardini A., Salleo S., Impact of the leaf miner Cameraria ohridella on photosynthesis, water relations and hydraulics of Aesculus hippocastanum leaves, Trees 17 (2003) 376-382.

[14] Salleo S., Water relations of two Sicilian species of Senecio (Groundsel) measured by the pressure bomb technique, New Phytol. 95 (1983) 179-188.

[15] Salleo S., Nardini A., Lo Gullo M.A., Ghirardelli L.A., Changes in stem and leaf hydraulics preceding leaf shedding in Castanea sativa L., Biol. Plant. 45 (2002) 227-234.

[16] Salleo S., Nardini A., Raimondo F., Lo Gullo M.A., Pace F., Giacomich P., Effects of defoliation by the leaf miner Cameraria ohridella on wood production and efficiency in Aesculus hippocastanum growing in north-eastern Italy, Trees 17 (2003) 367-375.

[17] Thalmann C., Freise J., Heitland W., Bacher S., Effects of defoliation by horse chestnut leafminer (Cameraria ohridella) on reproduction in Aesculus hippocastanum, Trees 17 (2003) 383-388.

[18] Tyree M.T., Patiño S., Bennink J., Alexander J., Dynamic measurements of root hydraulic conductance using a high-pressure flowmeter in the laboratory and field, J. Exp. Bot. 46 (1995) 83-94.

[19] Weltzin J.E., Archer S.R., Heitschmidt R.K., Defoliation and woody plant (Prosopis glandulosa) seedling regeneration: potential vs. realized herbivory tolerance, Plant Ecol. 138 (1998) 127-135.

[20] Yang S., Tyree M.T., Hydraulic architecture of Acer saccharum and A. rubrum: comparison of branches to whole trees and the contribution of leaves to hydraulic resistance, J. Exp. Bot. 45 (1994) 179-186. 